\title{
PSYCHOLOGICAL CONDITION OF GRIEVING FAMILY MEMBERS AND THEIR RESOCIALIZATION
}

\author{
Olena Kostyuk ${ }^{1}$, Olena Boychuk ${ }^{2}$ \\ ${ }^{1}$ P.L Shupyk National Medical Academy of Postgraduate Education, National University of \\ "Kyiv Mohyla Academy", Kyiv, Ukraine \\ ${ }^{2}$ National University of "Kyiv Mohyla Academy", Vadym Hetman Kyiv National Economic \\ University, Kyiv, Ukraine
}

\begin{abstract}
Introduction. Personal development in competitive and adverse conditions gives us plenty of examples that show negative behavior and incapability of making peace between nations. The situation in the world today confirms the previous statement, Ukraine suffers more than many other countries because of the powerful neighbor from the East who forces our country to accept his conditions. The war in Eastern Ukraine is the consequence of this irrational and atavistic tendency. We are the victims of the aggravation between two dialectic processes of social activism: disconnection (destructive situations, ATO, loss of a family member, family break up, heightened level of aggression in the community) connection (constructive and creative appearances, adaptation in conditions of forced immigration, posttraumatic growth, resocialization after overcoming trauma, tendency for reconciliation, personal growth in a new profession).

This is the reality that requires psychological science and practice to find quick and accurate answers because the goal is to save people's mental health in military and mobilization conditions.
\end{abstract}

Purpose. The main goal of the research is to generalize the information about psychological features of the people who have experienced loss. Also to spot the stages of women's post-loss resocialization and factors that have a positive impact on that resocialization.

Methodology. The authors of this paper made research on the psychological features of the people who have experienced loss due to military situation in the East of Ukraine and who need psychotherapy to help the process of resocialization. The facts stated in the paper that helped to analyze the situation were received during work in the period of 2015-2018 at the center of psychosocial rehabilitation at National University of "Kyiv Mohyla Academy". 5370 people have addressed to the center to get help during this period. 1414 of them have gotten individual consultations, 3953 have participated in group therapies.

Keywords. military losses, mental effects, types of lesions, gender characteristics, means of assistance and re-socialization

Introduction. Viktor Muzhenko, the Chief of the General Staff and the commanding officer of the Armed Forces of Ukraine has reported that the estimated death toll in the East of Ukraine 2014-2017 includes 4,000 members of Ukrainian forces which means that the 
amount of families who lost their relative is practically same. We can assume that about 12-18 thousand people had to deal with the problem of losing a family member because of AntiTerroristic Operation Zone. For each one of those people, it was a period when their usual norms and everyday lifestyle was either ruined or changed completely because of the tragic events that happened in their families.

To our point of view, the actuality of grief and loss problem is underrated. Considering our experience, we can state that widows and mothers after loss deserve the same attention as ATO zone veterans or their family members. Today's problem is that due to the heightened interest for ATO zone veterans, and their rehabilitation those who have lost their beloved ones during the war are not interested in coming to professional psychologists and psychotherapists themselves. Because this problem is not well represented in scientific researches, we have practically no information about the flow of the grieving process and its dynamic. We also do not know the amount of people who have pathological kind of grief and the amount of people whose resocialization is productive with or without psychotherapy.

The actuality of the research made on secondary socialization becomes even more important considering the fact that this process can have many complications or sometimes even stops for those who have faced loss. To be stuck in grief and total lack of re-socialization leads to:

- Deprivation in all the lifestyle conditions, psycho-physiological, social, economic, cognitive-information, professional, etc.

- The primitivization and deformation of the lifestyle strategy, self-doubt and upbringing destructive scenario into life.

- Immune system disorders and lack of resilience to life challenges.

- Constricted social circle, sometimes total estrangement.

Talking about widows who have children, all the problems also transfer to them. Social deprivation of parents who lost their childlchildren spreads itself on the whole family system. The importance of creating special conditions that can help working with those who are traumatized by loss is confirmed by the fact that the closest environment of the patient gets affected too. Honoring the lives of the dead and supporting their families can also be a factor that helps to form a stronger patriotic spirit of the nation and its younger generation. 
Purpose. The main purpose of this paper is to describe the psychological features of those who had to deal with loss, to define the stages of resocialization for those women who have lost their beloved ones and the conditions that help to overcome loss.

Design\Methodology. Work in the center of psychological rehabilitation of National University of «Kyiv-Mohyla Academy» during 2015-2018 has become the main material for this article. 5370 people came to the center to get help during this time, 1417 of them have gotten individual consultation, 3953 took part in a group training.

Chart 1.

\begin{tabular}{|l|r|r|r|r|r|}
\hline & $\mathbf{2 0 1 5}$ & $\mathbf{2 0 1 6}$ & $\mathbf{2 0 1 7}$ & $\mathbf{2 0 1 8}$ & total \\
\hline total & $\mathbf{7 1 3}$ & $\mathbf{9 4 2}$ & $\mathbf{1 6 1 3}$ & $\mathbf{2 1 0 2}$ & $\mathbf{5 3 7 0}$ \\
\hline individual & 60 & 383 & 417 & 557 & 1417 \\
\hline group & 653 & 559 & 1196 & 1545 & 3953 \\
\hline
\end{tabular}

Among all the clients of our center women prevail man in 3.5 times, in fact, there are no men among those who came. We can suppose that this fact is related to gender stereotypes. Only $0.6 \%$ of all clients address for help due to "loss reason", women make $0.77 \%$ of them.

Chart 2.

\begin{tabular}{|l|l|l|l|l|l|l|}
\hline & $\mathbf{2 0 1 5}$ & $\mathbf{2 0 1 6}$ & $\mathbf{2 0 1 7}$ & $\mathbf{2 0 1 8}$ & total & $\begin{array}{l}\text { \% of people who } \\
\text { addressed for help }\end{array}$ \\
\hline total & 713 & 942 & 1613 & 2102 & 5370 & $0,6 \%$ \\
\hline Men & 154 & 243 & 349 & 448 & 1194 & $0 \%$ \\
\hline Women & 559 & 699 & 1264 & 1654 & 4176 & $0,77 \%$ \\
\hline
\end{tabular}

Such insignificant number of addresses with a problem of loss can be connected to several reasons:

- lack of attraction to psychotherapy of the mentioned type of people.

- The absence of information about the effectiveness of psychotherapy or people's disbelief in it.

- Fear of letting other people into one's private life.

In the past three years, we have created 3 special groups of psychotherapy for those people who have faced loss. Those groups included 28 women, each group had about 6-8 meetings. One third of those who have gone through individual and group therapy also took part in stabilizing group events of our center, like "Magic of breathing", "Soma-relax", "Right hemisphere drawing" or "Mandala therapy", patients visited our playback theater and also came for a consult because of problems with children. 
24 more women who had to deal with grief received individual help due to the CETA program (Common Elements Treatment Approach).

We used two well-tested forms of psychotherapy, a short-term with 5 sessions, middle term with 8-12 sessions. CETA uses cognitive behavioral therapy methods and is lead by the JHU Applied Mental Health Research group. We made a screening research on women who had psychotherapy to monitor their condition, the screening was made with the help of “mental health quiz "Kyiv Mohyla Akademy" Psycho-social Rehabilitation Center"). The screener was received from the JHU Applied Mental Health Research Group and adapted for use in Ukraine by the employees of National University of "Kyiv Mohyla Akademy" Psycho-social Rehabilitation Center.

Results. According to our research, all women who have faced loss experienced different symptoms before therapy, for example:

\begin{tabular}{|l|r|}
\hline Symptoms & Percent \\
\hline Depression & $100 \%$ \\
\hline PTSD & $100 \%$ \\
\hline Anxiety & $45,80 \%$ \\
\hline Lowered interest in functioning & $91,70 \%$ \\
\hline Increased pressure & $70,80 \%$ \\
\hline Alcohol consumption & $25 \%$ \\
\hline
\end{tabular}

The following data is not representative of all women who have faced loss, women in our research are only those who came to get help themselves after they realized they cannot deal with the problem alone. Even though our research contains only a small part of women with the following problem it can be stated that this category of people needs a specialized, sometimes even complex help.

Due to our quiz, main complains are sleep disorder, fear of financial incapability, frightening memories, negative thoughts, panic attacks, bad mood, crying, nervous tremor, anger, suicidal thoughts, anxiety, lack of energy, fear of death, loss of life sense.

Dr. Yalom states that the process of overcoming loss has gender features: "a husband and a wife grieves differently, they cannot understand and support each other; one's grief disturbs other one's grief, makes disagreements and cools down the feelings between them. Many women feel the need to come back to their loss, they do it and want reconciliation. 
Many of them try to work on their projects again, want to bring back everything they had before, they seek for something that can bring meaning into their life.

Men need to be taught how to feel and share their grief, instead of hiding or choking it inside them.

O.Chaban and B.Bezsheiko confirm in their research "War zone stress" that overcoming loss has gender peculiarities in conditions of modern Ukraine.

The results of this research have shown that the same percentage of both men and women who have been in war zone areas have PTSD symptoms, meaning $20.9 \%$ and $20.0 \%$, women had a higher point on each symptom.

Our experience that was gained in three years of studies shows that that the problem of loss disturbs social connections of a patient, sometimes even breaks their social life. While observing the process of secondary socialization after loss we can state that it has two stages.

The first stage is desocialization, it is the opposite to socialization, this part of the process is based on the fact that women need to change their social role, from wife to widow.

Desocialization happens to numerous reasons:

1. Shock with the deprivation in all life spheres.

2. Devaluation of previous socialization experience.

3. Sharp change of social conditions.

4. Loss of the previous identity as mother, daughter, wife, etc.

5. Loss of previous opportunities.

Women have to reject their previous gender-role model as mother, wife, housewife, employee, her habits and skills to make a transition to a new stage because those usual roles become impossible or divergent in a new status.

We have often observed total or almost total social isolation, minimization of action that only maintains life in family or work system on the smallest level.

Many patients give up on their social interactions and opportunities, their faith, ideology, life values change completely. They experience a full range of reactions from 
devaluation of their personality, their life and life of their closest people to devaluation of life in general, micro and macro-social environment of a widow or a mother who lost her child.

Psycho-emotional condition of women experiences many changes, they avoid joy and feel constant pressure, they try to come back to grief again but in a new symbolic status.

Based on our data, desocialization has different stages and duration.

- Superficial short duration 1-6 month. The structure of the personality and life values remain the same.

- Deep- 7-23 month, the personality is ready for full change of their life values, social structure and relationship with other people and the environment.

- $\quad$ Pathological- more than 2 years. A person is stuck in the desocialization phase.

Total estrangement, loss of moral guidelines. This stage requires special, professional help.

Among those who had individual therapy, almost every person who has overcome loss mentions that external factors have been the main impulse for recovery.

The next stage is resocialization. The moment, when women come back to their usual life but in new circumstances, resocialization happens. It can be either under social pressure or because of inner desire.

Factors that promote resocialization:

- Search of life sense, revaluation of inner priorities, self-concept change.

- Realization of one's life-tasks.

- Social and family support. Renewing old social contacts or making new ones.

- Government's support for resocialization and financial support.

- Self-regulation skills.

- Healthy relationship with a dead one in the past.

Our experience based on individual and group psychotherapy shows that resocialization starts under pressure, women have to come back to their work and duties because of needs.

Social stigmatization of widows and mothers who lost their children on war leads to creating new social communities where women have support and comfort, where they feel 
unity. Furthermore, women enter a different stage of socialization, many of them change the social environment or job, life position and some aspects of their personality.

Resocialization also has different forms:

- Superficial- when a person stays in the same place in life but changes some strategies of behavior, for example, a widow who does not change her job but in addition has to do things that were usually done by her lost husband. She does not change her life position completely but still tries to support her life and life of her children on the same level.

- Deep- when a person changes their life completely, brings new social connections into it, creates new projects, changes a job or continues to work it the same place but considers new approaches. These changes are the manifestation of a new lifestyle, they show the unwillingness to follow old rules and norms.

- Unstable - when a person can't find a new sense for a long time and goes from desocialization to resocialization on and on when they can't form a new self-concept.

When the process of resocialization is in its starting position, supporting communities are very helpful, they provide psychological, physical and financial support. Widows and mothers who lost their children are looking for different resources that can be helpful for the family of a victim, they look for clothes and shoes for children, find doctors and psychotherapists, potential low-priced vacations.

Unfortunately, after some time these communities slow down the process of resocialization when members of the community start to compete with each other or compare themselves to others. It can drag resocialization down or bring a woman back to desocialization, which usually happens to a superficial form of resocialization.

The following situation is provoked by social stereotypes about women being slavish and incapable of autonomic living which puts this gender in the victim position.

After four years of war in Ukraine we can observe a huge variety of resocialization scenarios: getting married again, creating new business projects, changing a job, starting a volunteering or charity program, over concentrating on children, grandchildren, relatives, implementation of art projects, etc. 
This way we consider desocialization and resocialization as parts of the socialization process, to be specific "secondary socialization". It occurs after a serious loss of someone close and requires a significant overview of old social habits and functions. Society plays an important role in secondary socialization process: nation, family, and environment.

To promote the process of secondary resocialization we suggest:

1. On the government level

- To refine the government politic about supporting families who lost their closest people.

- Social advertisement that honors the lives of the dead. Advertise that sets a healthy relationship with the family who lost their beloved people, not stigmatizing one.

- Adding a ritual of honoring lives of the fallen to national celebrations and important dates.

- Creating the virtual memory book of the dead by the Ministry of Defence.

2. On the mass level.

- Rituals of honoring the memory of the dead and their families.

- Non-formal support. Creating support groups that can help to compensate lost opportunities or to fight social isolation, etc. also different kinds of support on the micro-social level can be helpful.

- Formation of specific moral and ethical principles that can help to build a healthier and stronger relationship with those families who lost one of their closest people.

- Social flash-mobs like "join mom of your lost friend for a tea", "be a Santa Claus for your dead friend's children", "share the warmth of your heart", "teach a son of your dead friend how to play football".

3.On the professional level.

- All widows and parents of the dead ATO members need to have a right for professional, prolonged, free of charge help in psycho-social rehabilitation centers.

- For those specialists who work with the mentioned type of clients have been created specific supervising systems that prevent emotional burnout.

- Special analytical and monitoring systems created in order to know the effectiveness of the treatment.

- Methodical and educational centers for training crisis psychologists. 
Conclusions. This way we can conclude that the growth of military loss in the country makes it not only a personal problem but a national problem. Society has to be supportive and become a resource of help for those who lost their beloved ones. By giving a life of their family members away in order to help the nation those people have a full right to ask for the nation's support.

Society has to elaborate a moral imperative about the attitude towards dead ones and their families, people have to create a healthy environment to support the mental health of those who struggled the most at war. More specialists are needed to provide a professional help to the victims, those who will raise the psychological culture of the nation and help to overcome the problem of grief. The therapists need to have a positive experience with solving existential questions because it allows to stabilize the psychological condition of the patient as well as has a positive impact on the professional life of the therapist.

\section{References.}

Singh N.; Hopkins J.; Bogdanov S. Community Mental Health Intervention with WarAffected Persons in Ukraine// URI: http://ekmair.ukma.edu.ua/handle/123456789/11947

Murray L.; Haroz E.; Doty S. B.; Singh N.; Bogdanov S.; Bass J.; Dorsey S.; Bolton P. Testing the effectiveness and implementation of a brief version of the Common Elements Treatment Approach (CETA) in Ukraine: a study protocol for a randomized controlled trial// URI: http://ekmair.ukma.edu.ua/handle/123456789/13866; https://doi.org/10.1186/s13063018-2752-y

Doty S. B.; Haroz E.; Singh N.; Bogdanov S.; Bass J.; Murray L.; Callaway K.; Bolton P. Adaptation and testing of an assessment for mental health and alcohol use problems among conflict-affected adults in Ukraine// URI: https://doi.org/10.1186/s13031-018-0169-6

Murray L.; Haroz E.; Dorsey S.; Bolton P. (2014) A Common Elements Treatment Approach for Adult Mental Health Problems in Low- and Middle-Income Countries// Cognitive and Behavioral Practice N21(2):p.111-123, 2014. Reads https://www.researchgate.net/publication/261291940 A Common Elements Treatment App roach_for_Adult_Mental_Health_Problems_in_Low-_and_Middle-Income_Countries

Бойчук О.С., Костюк O.I. (2017) Феноменологія втрат: деякі психологічні особливості переживання вдовами та матерями, що втратили рідних в АТО / Новітні чинники впливу на формування особистості студента - майбутнього лікаря: Матеріали XVII міжн. наук.-практ. конференції, Київ, 2017 р. - К.: ПВНЗ КМУ УАНМ, 2017. - С. 29-30

Гошовський Я. (2008) Ресоціалізація депривованої особистості : монографія. Дрогобич : Коло, 2008. - 480 с.

Десоциализация и ресоциализация//Кравченко А.И. (2001) Культурология: Учебное пособие для вузов.--М., 2001. 
Лангмейер И., Матейчек 3. (1984) Психическая депривация в детском возрасте; пер. Г.А. Овсянникова. - Изд. 1-е русск.- Прага : ЧССР : Авиценум. Медицинское издательство, 1984. - 334 с 